Proceedings of the 24th International Symposium "The Environment and the Industry" (E-SIMI 2021), 24 September 2021, online event

\title{
Physical-chemical properties of the surface water from shallow lakes of the Matita-Merhei Unit, Danube Delta, Romania: current state and environmental significance
}

\author{
IRINA CATIANIS*, DUMITRU GROSU, ADRIANA MARIA CONSTANTINESCU, LAURA \\ TIRON DUTU, OANA DOBRE
}

National Research and Development Institute for Marine Geology and Geoecology, GeoEcoMar, 23-25 Dimitrie Onciul Street 024053, Bucharest, Romania

*Corresponding author: irina.catianis@geoecomar.ro

$\begin{array}{lll}\text { Received: } & \text { Accepted: } & \text { Published: } \\ \text { 09.08.2021 } & 20.09 .2021 & 17.12 .2021\end{array}$

\begin{abstract}
.
This study aimed to assess the water quality of certain lakes (Bogdaproste, Trei Ozere and Radacinos) belonging to the Danube Delta, Romania. Deltaic ecosystems are subject to natural and man-made environmental stressors. If in the past these ecosystems were largely threatened by eutrophication and organic/inorganic pollution, nowadays, we must focus on hydro morphological impact. This refers to the physical character and water content of the aquatic environment, impoundment (dams and flood gate), channelization and embankments, as well as clog/siltation of lakes. Environmental parameters are those physical, chemical and biological indicators used to characterize a freshwater body, and, which vary in time and space. In this regard, 44 water samples were collected in the dry season from the three lakes, for analysis of physical-chemical quality indicators. A series of physical (T, EC, TDS, turbidity, TSS, transparency) and chemical parameters ( $p H, D O$, nutrients, $\mathrm{SiO}_{2}, \mathrm{TOC}, \mathrm{SO}_{4}^{2-}$, ORP, technophilic elements) were considered. The results obtained in the physical-chemical analyses revealed that the majority of parameters were found in line with enforcing environmental regulations. Despite that, $\mathrm{P}-\mathrm{PO}_{4}{ }^{3-}$ and $\mathrm{Cd}$ concentration results of some samples were found above certain permissible limits set by the normative. Probably, these inadvertences can be associated with local conditions of the transitional deltaic environment. Further analysis is required conducting repeated measurements with the same question, meaning a routine monitoring, especially $\mathrm{P}_{-} \mathrm{PO}_{4}{ }^{3-}$ and $\mathrm{Cd}$. Finally, it was concluded that the results of this study showed a good quality of water in investigated lakes that did not pose potential health and environmental problems related to the biota.
\end{abstract}

Keywords: Danube Delta, environment, physical-chemical properties, surface water, water quality

\section{INTRODUCTION}

Surface waters (lakes, rivers, streams, reservoirs, wetlands, estuaries) are habitats of considerable significance for aquatic wildlife and human needs, since they yield water-related ecosystem services (domestic, industrial and agricultural use, as well as food and other useful products) [1, 2]. Worldwide, all these freshwater ecosystems may be severely impaired by a series of natural and anthropogenic disturbances with negative consequences on their structure and function. According to the objectives of the Millennium Development Goals (MDGs), especially, the Goal 14: Life Below Water, it is imperative to integrate principles and programmes of sustainable development and to mitigate the loss of environmental resources [3]. As well, the Water Framework Directive [4] appeals all rivers, lakes, transitional and coastal waters of the European Union to be in good 
ecological status in the near future. From this perspective, adequate monitoring, surveillance, management, and maintenance programs must be accomplished constantly to acquire reliable instruments for a better insight into aquatic ecosystems [5]. Lakes are complex ecosystems, comprising distinct habitats which are sustained of several in-lake processes (biological, physical and chemical). The alteration of their environmental quality can occur due to climate seasonality, inputs from the watershed, harmful algal blooms, anoxic conditions, flooding, sediment plumes etc. $[6,7]$. Particularly, the Danube Delta virgin wetlands and its labyrinthine hydrographic network with lakes and ponds are nationally and internationally recognized as home to several flora and fauna iconic unique wildlife species [8]. Apart from these, the lands and water from deltaic edifice provide and support our nation's ecosystem services represented by numerous natural resources, wild open spaces, freshwater, flood control, nutrient cycling, and unique wildlife and recreation opportunities [9]. Thereby, we must take action in order to protect Danube Delta's wetlands and waters for the near future. The lakes chosen for this study located further away from the Danube River input are shallow and confined water bodies, lacking self-cleansing flow condition, susceptible to clogging (due to abundant organic material) and therefore leading to accumulation of different impurities (organic and inorganic). Contamination of freshwater ecosystems may have a negative impact on the ecologically-associated habitats and quality of fish and other wildlife species. In this context, the assessment of the existing water physical-chemical properties and current aquatic environmental circumstances may subsequently contribute to prefigure future trends and challenges of potential natural and anthropogenic stressors.

\section{MATERIALS AND METHODS}

\section{Study area}

The Danube Delta edifice, located in Romania (Fig. 1a), is a component of the European's major geo-system Danube River - Danube Delta - Black Sea [10]. The study was conducted in the southern Matita-Merhei interdistributary depression (Fig. 1b), which joins to the fluvial Danube Delta plain, in three shallow lakes, namely Bogdaproste, Trei Ozere and Radacinos (Fig. 1c). This area is an integral part of the Danube Delta Biosphere Reserve (DDBR) area, a vast natural wetland having great biological, ecological and environmental importance. The DDBR wetlands and coastal zones have the role of supporting spaces of migratory species [11], as well as spawning areas for fisheries, remarking also the role of coastal wetlands in maintaining the balance of sediment dynamics $[12,13]$. For this reason, these territories have been designated official, under different conventions, in terms of cultural heritage protection, as UNESCO World Heritage Sites, Biosphere Nature Reserve and Wetland of International Importance [14]. Generally, the three lakes studied are located between the Chilia and Sulina Danube's distributaries, in a hydrodynamic area, less influenced by the Danube River alluvial input. They are shallow lakes, and have large surface areas as: Bogdaproste (435 ha), Trei Ozere (437 ha) and Radacinos. The investigated area has no single Danube River input, but is poorly maintained by inflow from many small tributary streams/channels. The water balances from input to output vary as a function of the limited water flow, especially during the summer-autumn period [8].
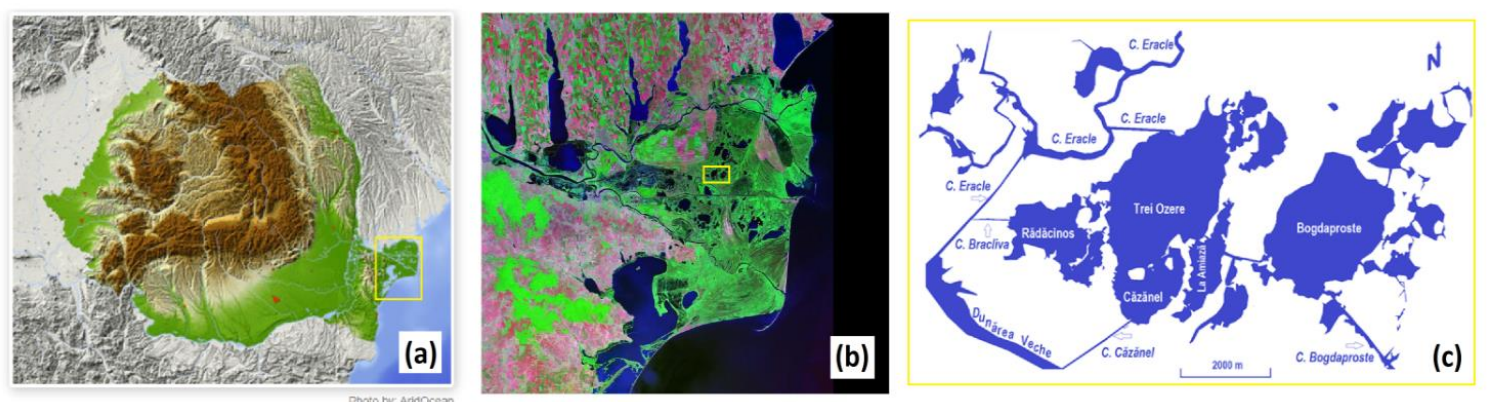

Fig.1. Location of the Danube Delta in Romania (a), Danube Delta - general view (b) and the study area (c) (Base maps: https://google.com) 


\section{Sampling locations and sample collection}

A total number of 44 water samples were collected during August-September 2020, in the conditions given by the downward trend in Danube waters and drought environs (Fig. 2). The water samples for the physical-chemical analysis were georeferenced (Garmin Montana 680), (Fig. 3) and were collected from the surface layer at a depth of about $0.5 \mathrm{~m}$ in polystyrene/glass bottles with a capacity of 500-1000 ml. Cellulose Nitrate Membrane filters $(0.45 \mu \mathrm{m})$ were used for samples pretreatment. The samples were properly prepared, preserved and secured (low temperature and no light) for the further required chemical analyses.

\section{Physical-chemical analysis}

The water samples were tested and analyzed for physical (in situ) and chemical (ex situ) parameters by using standard methodologies. The physical-chemical properties of water samples were determined based on temperature $\left({ }^{\circ} \mathrm{C}\right), \mathrm{pH}$ (unit.), dissolved oxygen concentration $(\mathrm{mg} / \mathrm{L})$ and saturation (\%), N-NH${ }_{4}^{+}(\mathrm{mg} / \mathrm{L}), \mathrm{N}_{-} \mathrm{NO}_{2}{ }^{-}(\mathrm{mg} / \mathrm{L}), \mathrm{N}^{-\mathrm{NO}_{3}}{ }^{-}(\mathrm{mg} / \mathrm{L}), \mathrm{P}_{-} \mathrm{PO}_{4}{ }^{3-}(\mathrm{mg} / \mathrm{L}), \mathrm{SiO}_{2}(\mathrm{mg} / \mathrm{L})$, TOC $(\mathrm{mg} / \mathrm{L}), \mathrm{EC}(\mu \mathrm{S} / \mathrm{cm}), \mathrm{TDS}(\mathrm{mg} / \mathrm{L}), \mathrm{SO}_{4}{ }^{2-}(\mathrm{mg} / \mathrm{L})$, Turbidity (NTU), TSS (mg/L), VDS (m), ORP (mV) and $\mathrm{Cd}, \mathrm{Co}, \mathrm{Cr}$ total, $\mathrm{Cu}, \mathrm{Ni}, \mathrm{Pb}$ and $\mathrm{Zn}(\mu \mathrm{g} / \mathrm{L})$.

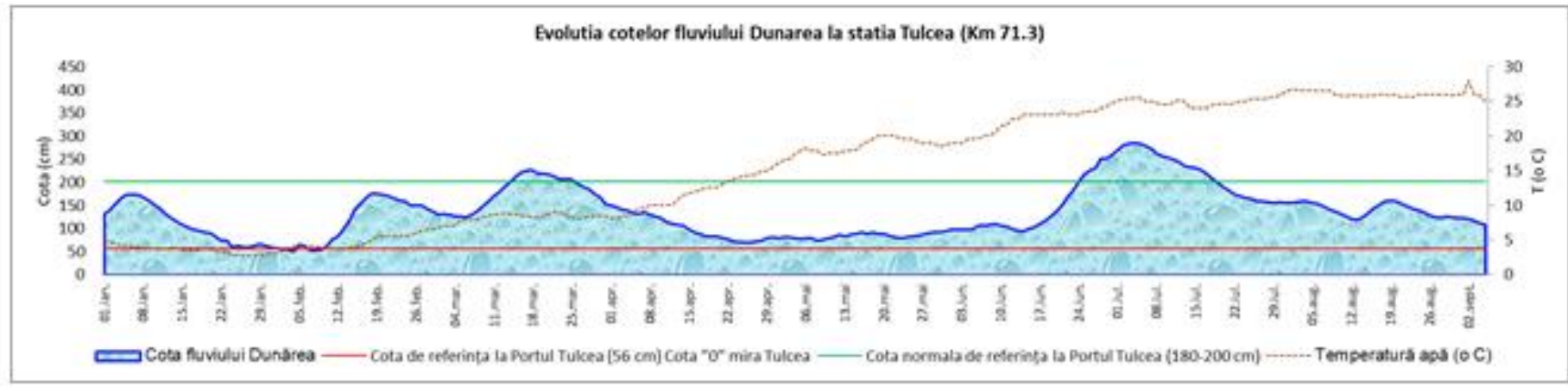

Fig. 2. Trends in the Danube River flows variations, measured at the Tulcea Port (km 71.3) in 2020

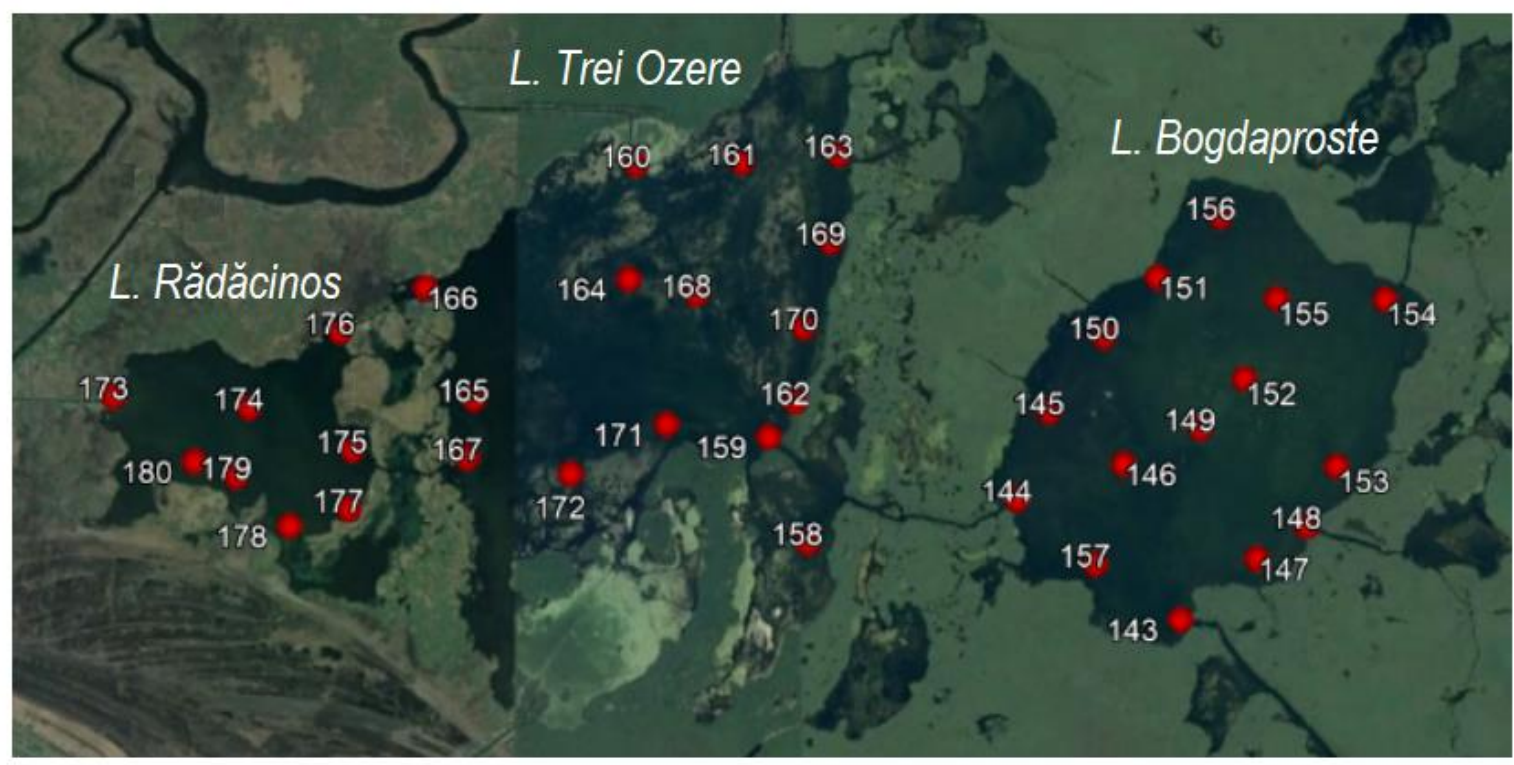

Fig. 3. GPS locations for sampling points

The samples were investigated using water sampling field equipment and techniques as: Secchi disc, WTW Multiline P4 Multiparameter, Hach 2100 P Turbidimeter, Portable Spectrophotometers HACH DR 5000 UV-Vis and DR 2000. The physical-chemical testing and analysis protocols were performed according to standard methodologies, at specific research laboratories - National Institute for Research and Development of Marine Geology and Geo-ecology - GeoEcoMar. In addition, the concentrations of a number of technophilic elements $(\mathrm{Cd}, \mathrm{Co}, \mathrm{Cr}$ total, $\mathrm{Cu}, \mathrm{Ni}, \mathrm{Pb}$ and $\mathrm{Zn}$ ) were 
investigated in instantaneous sampling points to detect possible contamination with heavy metals. In this regard, expert laboratories (National Research and Development Institute for Industrial Ecology - Ecoind) were asked to process and analyze certain samples in line with their in-house laboratory techniques and procedures [15].

\section{Data processing}

The data obtained from the water samples were compared with several national and international environmental standards that were used as the basis for the interpretation of our results, in order to evaluate the water quality status.

\section{RESULTS AND DISCUSSION}

This study plays a key role in understanding hydro-chemical functioning of lacustrine ecosystems and represent a basis for monitoring the physical-chemical quality of water in the study area. The results of the various physical - chemical analyses carried out on the surface water of the Bogdaproste, Trei Ozere and Radacinos lakes are shown below. In general, the physical-chemical parameters measured in Bogdaproste, Trei Ozere and Radacinos lakes, showed comparable average values. Overall, no significant increases/decreases were recorded, except for some specific local situations, which will be presented further on.

\section{Water temperature, $\mathrm{pH}$ and dissolved oxygen}

Water temperature is a controlling factor regulating the temporal and spatial dynamics of aquatic life and habitats [16]. The temperature of all water samples was measured in situ, and showed relatively high values, closely related to the evolution of the air temperature, (characteristic for August-September period), and the dynamic action of the wind. The measurements did not show significant differences between investigated lakes, so: Bogdaproste L. $\left(25.9^{\circ} \mathrm{C} \div 27.7^{\circ} \mathrm{C}\right)$, Trei Ozere L. $\left(27.7^{\circ} \mathrm{C} \div 29.7^{\circ} \mathrm{C}\right)$ and Radacinos L. $\left(27.1^{\circ} \mathrm{C} \div 27.9^{\circ} \mathrm{C}\right)$.

The $\mathrm{pH}$ indicator refers to the acidity or alkalinity of the water [17] having considerable effects upon the biological activity, some properties of the water body and influencing the toxicity and bioaccumulation of contaminants [18], existing in the aquatic environment. The majority of aquatic organisms prefer a $\mathrm{pH}$ range of $6.8 \div 9.0$ [19]. The $\mathrm{pH}$ of the water samples in this study registered neutral and slightly alkaline $\mathrm{pH}$ values [20], as follows: Bogdaproste L. (7.97 $\div 8.82$ ), Trei Ozere L. $(7.4 \div 8.54)$ and Radacinos L. $(7.4 \div 8.4)$. Anyway, there is no evident sign of acidity or alkalinity in the investigated water samples, since the $\mathrm{pH}$ of most lacustrine environment is on the alkaline side of neutrality. In this case, slightly alkaline $\mathrm{pH}$ values can be attributed to local conditions of the transitional deltaic environment.

Dissolved oxygen (DO) is an important parameter in assessing water quality due to its influence on aquatic biota ecosystem and hydro chemical characteristics of the aquatic environment [17]. The amount of dissolved oxygen in the water is facilitated by the dynamic flow regime of the water and by the action of the wind. Measurements performed on tests samples classified the samples in the category of well oxygenated surface waters, since they contain more than $8 \mathrm{mg} \mathrm{O}_{2} / \mathrm{L}$ [20]. Dissolved oxygen of water samples ranged in this way: Bogdaproste L. $(7.05 \mathrm{mg} / \mathrm{L} \div 12.81 \mathrm{mg} / \mathrm{L})$, Trei Ozere L. (3.45 mg/L $\div 13.58 \mathrm{mg} / \mathrm{L})$ and Radacinos L. (3.61 mg/L $\div 14.07 \mathrm{mg} / \mathrm{L})$. In general, no dissolved oxygen deficiency was found in the investigated samples, excepting two samples collected from Trei Ozere L. (DD20-167 = $3.45 \mathrm{mg} / \mathrm{L}$ ) and Radacinos L. (DD20-174 = 3.61 mg/L), which belong to the category of moderate oxygenated surface waters.

\section{Nutrient regime}

Anthropogenic-induced changes in nutrient loadings (especially nitrates and phosphates) impact lacustrine ecosystems (i.e., eutrophication) and functioning of aquatic communities (due to $\mathrm{N}$ and $\mathrm{P}$ compound's toxicity if they exceed certain alert limits) [17]. Routinely, to ascertain the impact of nutrient loading on the water quality as a result of anthropogenic activities (i.e., leaching of orthophosphate, nitrate and organic matter) and on the population of freshwater microalgae 
(harmful algal bloom) a number of specific indicators are taken into account. Thereby, in this study, the determination of the concentration $(\mathrm{mg} / \mathrm{L})$ of the following components was considered $\mathrm{N}$ $\mathrm{NH}_{4}{ }^{+}, \mathrm{N}-\mathrm{NO}_{2}{ }^{-}, \mathrm{N}-\mathrm{NO}_{3}{ }^{-}, \mathrm{P}-\mathrm{PO}_{4}{ }^{3-}$, as well as $\mathrm{SiO}_{2}$ and TOC. Consequently, the $\mathrm{N}-\mathrm{NH}_{4}{ }^{+}$concentration values identified in the samples met the water quality of Class 1 standard $(0.4 \mathrm{mg} / \mathrm{L})$ [20]. The values were low, as Bogdaproste L. $(0.004 \div 0.032 \mathrm{mg} / \mathrm{L})$, Trei Ozere L. $(0.002 \div 0.03 \mathrm{mg} / \mathrm{L})$ and Radacinos L. $(0.002 \div 0.022 \mathrm{mg} / \mathrm{L})$. Then, the ${\mathrm{N}-\mathrm{NO}_{2}}^{-}$concentration values determined in the samples met the water quality of Class $1(0.01 \mathrm{mg} / \mathrm{L})$ and $2(0.03 \mathrm{mg} / \mathrm{L})$ standard [21], being registered the following amounts: Bogdaproste L. $(0.005 \div 0.013 \mathrm{mg} / \mathrm{L})$, Trei Ozere L. $(0.005 \div$

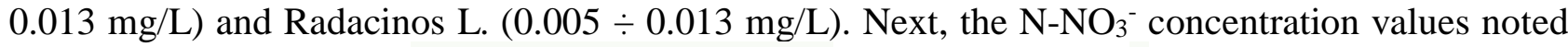
in the samples met the water quality of Class 1 standard $(1 \mathrm{mg} / \mathrm{L})$ [20]. The variations were insignificant as Bogdaproste L. $(0.01 \div 0.03 \mathrm{mg} / \mathrm{L})$, Trei Ozere L. $(0.01 \div 0.03 \mathrm{mg} / \mathrm{L})$ and Radacinos L. $(0.01 \div 0.15 \mathrm{mg} / \mathrm{L})$. Instead, the $\mathrm{P}-\mathrm{PO}_{4}{ }^{3-}$ concentration showed great variations. The investigated water samples from all lakes were categorized in general as acceptable; they met the water quality of Class $1(0.1 \mathrm{mg} / \mathrm{L})$ and $2(0.2 \mathrm{mg} / \mathrm{L})$. Withal, some samples from Bogdaproste and Trei Ozere lakes are categorized as unacceptable, since they did not meet the reference standard, reaching the Class $3(0.4 \mathrm{mg} / \mathrm{L}), 4(0.9 \mathrm{mg} / \mathrm{L})$ and $5(>0.9 \mathrm{mg} / \mathrm{L})$ standard [21]. High phosphate concentrations (versus reference standards), pose a risk to the normal functioning of aquatic ecosystems, leading to eutrophication, oxygen deficiency and reduced biodiversity. Generally, the high orthophosphate contents might be an indication of naturally occurring contaminants (i.e., atmospheric deposition, natural decomposition of rocks and minerals, dissolution of soluble inorganic materials, plant litter, animal decomposition sedimentation etc.), and/or anthropogenic pollutants occurring as a result of human-induced activities (domestic, agricultural and/or industrial). Therefore, continuous monitoring of orthophosphates in water quality is required. Silica $\left(\mathrm{SiO}_{2}\right)$ content is a valuable proxy for diatoms (the largest type of phytoplankton algae) and macrophytes (aquatic plants that grows in or near water, being emergent, submerging, or floating). All the samples tested in this study were below the standard limit of rivers and lakes variation $(1 \div 30 \mathrm{mg} / \mathrm{L})$ [17]. Silica levels in water samples ranged as follows: Bogdaproste L. $(2.63 \div 5.13 \mathrm{mg} / \mathrm{L})$, Trei Ozere L. $(1.13 \div 1.70 \mathrm{mg} / \mathrm{L})$ and Radacinos L. $(0.59 \div 2.01 \mathrm{mg} / \mathrm{L})$. Total organic carbon (TOC) is the amount of carbon found in an organic compound (dissolved and undissolved organic substances in water) and is often used as a non-specific indicator of the approximate level of organic contamination [21]. In this study, the TOC concentrations have low values in comparison to the reference standard for natural waters $(1 \div 30 \mathrm{mg} / \mathrm{L})$, placing the tested water from all investigated samples in a good condition [22]. The ranges were as follows: Bogdaproste L. $(1.2 \div 26.7 \mathrm{mg} / \mathrm{L})$, Trei Ozere L. $(4.55 \div 11 \mathrm{mg} / \mathrm{L})$ and Radacinos L. $(4.9 \div 15.5 \mathrm{mg} / \mathrm{L})$.

\section{Electrical conductivity (EC), Total Dissolved Solids (TDS) and sulfate ions ( $\left.\mathrm{SO}_{4}{ }^{2-}\right)$}

$\mathrm{EC}$ is a measure of water's capability to pass an electrical flow, being receptive to variations in inorganic dissolved solids, generally mineral salts. Significant changes in conductivity have strong interrelationship with pollution level (e.g., wastewater discharges) [17]. EC levels of all water samples investigated within this study met the water quality of Class 1 standard $(500 \mu \mathrm{S} / \mathrm{cm})[20]$. The level of variations was Bogdaproste L. $(306 \div 342 \mu \mathrm{S} / \mathrm{cm})$, Trei Ozere L. $(305 \div 364 \mu \mathrm{S} / \mathrm{cm})$ and Radacinos L. (325 $\div 357 \mu \mathrm{S} / \mathrm{cm})$. TDS incorporates the total of inorganic salts and some small amounts of organic matter that are dissolved in water, being used as an indicator test to determine the general quality of the water [17]. The results of TDS concentrations obtained in this study classified the tested water in a good condition, according to the recommendation level corresponding to fresh water $(0 \div 1000 \mathrm{mg} / \mathrm{L})$ [23]. TDS interval variation concentrations were Bogdaproste L. $(153 \div 171 \mathrm{mg} / \mathrm{L})$, Trei Ozere L. $(152.5 \div 182 \mathrm{mg} / \mathrm{L})$ and Radacinos L. (162.5 $\div 178.5 \mathrm{mg} / \mathrm{L}$ ). Sulphate is widely distributed in nature and may be present in natural water and in wastewater as $\mathrm{SO}_{4}{ }^{2-}$. The highest concentration of sulphate in natural water is attributable to leaching of natural deposits of sodium sulphate or magnesium sulphate [24]. Acquired results for $\mathrm{SO}_{4}{ }^{2-}$ have low values, within acceptable limits settled for water quality of Class 1 (60 mg/L), [21]. 
The ranges of variations were Bogdaproste L. $(27 \div 37 \mathrm{mg} / \mathrm{L})$, Trei Ozere L. $(29 \div 41 \mathrm{mg} / \mathrm{L})$ and Radacinos L. $(29 \div 39 \mathrm{mg} / \mathrm{L})$.

\section{Turbidity, Total suspended solids (TSS) and water transparency}

Turbidity or the muddiness/opacity of water [25] is a criterion of the ability of light to pass through water, assignable to suspended material (clay, silt, organic material, plankton) and other particulate materials in the water [26]. Elevated turbidity levels diminish water visibility and can have a harmful impact on freshwater fish and other aquatic life. In this study, the turbidity measured in water samples presented a series of slight variations, as: Bogdaproste L. (2.31 $\div 38.8$ NTU), Trei Ozere L. (1.86 $\div 12.7$ NTU) and Radacinos L. $(1.29 \div 11.9$ NTU). All the obtained values were in the field of variation of natural waters (1-1000, NTU) [17]. TSS is a quantitative analysis of the total (organic and inorganic) solid suspension particles ( $>2$ microns in size), that are retained on a standard TSS micron filter and dried to a constant weight at $105^{\circ} \mathrm{C}$ [27]. Measurements performed on samples classified the tested water in a good category, since they contain values which are below the acceptable level of TSS in the freshwater environment $(<40 \mathrm{mg} / \mathrm{L})$ [28]. The range of variation of the measured values was between Bogdaproste L. $(6 \div 53 \mathrm{mg} / \mathrm{L})$, Trei Ozere L. $(6 \div 18 \mathrm{mg} / \mathrm{L})$ and Radacinos L. ( $3 \div 47 \mathrm{mg} / \mathrm{L})$. Two higher values were observed in Bogdaproste L. (DD20-148 = $53 \mathrm{mg} / \mathrm{L}$; DD20-154 = $51 \mathrm{mg} / \mathrm{L}$ ) and one in L. Radacinos (DD20-173 = $47 \mathrm{mg} / \mathrm{L}$ ). These higher TSS concentrations might be related to local circumstances that are specific to the transitional lacustrine environment, so they cannot be considered harmful for the environment. Generally, TSS ranges from 1 to higher than 10,000 $\mathrm{mg} / \mathrm{L}$ [17]. Water transparency (Secchi Disk Visibility) is an indicator related to the health quality status of lakes, provided that the more transparent the water, the healthier it is. Transparency is controlled by the number of suspensions originated due to weather conditions (rain, wind etc.), or carried by the river water (suspended algae, suspended particles and dissolved organic matter). A decrease in transparency could indicate a decline in water quality. In this study, the transparency measured in situ showed variable values, as Bogdaproste L. $(0.3 \div 1.2 \mathrm{~m})$, Trei Ozere L. $(0.7 \div 1.2 \mathrm{~m})$ and Radacinos L. $(0.5 \div 0.85 \mathrm{~m})$. Most of the investigated aquatic sites have a low transparency (values $<2 \mathrm{~m}$ ).

\section{The oxido-reduction potential and technophile elements}

The oxido-reduction potential (ORP) designates the oxidation-reduction state of natural waters. Fresh waters (rivers, lakes) have the capacity to self-clean their water or break down waste products (i.e., contaminants, dead plants and animals). When the ORP value is high, there is lots of oxygen present in the water. In general, the higher the ORP value, the healthier the lake or river is, meaning that bacteria decomposing dead tissue and contaminants can work more efficiently. Despite that, even in healthy lakes and rivers, there is less oxygen and therefore, lower ORP values as we get closer to the bottom sediments. This is due to the fact that there are many bacteria working hard in the sediments to decompose dead tissue, and they use up a lot of the available oxygen. Actually, oxygen dissipates rapidly in the bottom mud (often in the first two centimeters) and ORP falls quickly. ORP is measured in tandem to dissolved oxygen because ORP may yield relevant data of the water quality and magnitude of pollution, if present [29]. The ORP may vary in natural waters from (-) $500 \mathrm{mV}$ to (+) $700 \mathrm{mV}$, and can either be above zero or below zero [18]. In healthy waters, ORP should read high, between 300 and $500 \mathrm{mV}$ [30]. In this study, positive ORP values were obtained in testing lake water samples, and results presented slight variations, as: Bogdaproste L. $(20 \div 55 \mathrm{mV})$, Trei Ozere L. $(40 \div 90 \mathrm{mV})$ and Radacinos L. $(40 \div 67 \mathrm{mV})$.

Technophilic elements derive from industrial effluents, agricultural, wastewater, and sewage runoff due to industrialization and rapid urbanization. They are of concern as contaminants of freshwater ecosystem due to their persistence and high toxicity to aquatic organisms [31]. In this study, the concentration $(\mu \mathrm{g} / \mathrm{l})$ of a number of technophilic elements (i.e., $\mathrm{Cd}, \mathrm{Co}, \mathrm{Cr}$ total, $\mathrm{Cu}, \mathrm{Ni}, \mathrm{Pb}$ and $\mathrm{Zn}$ ) was investigated in certain water samples to identify potential areas impacted by the past and present human activity. The investigated heavy metals, presented in general, low values that met the water quality of Class 1 standard [20]. The results of the analyses showed values below the 
detection limit of the experimented analytical method for the tested elements: $\mathrm{Cd}(<0.4 \mu \mathrm{g} / \mathrm{L})$, Co $(<0.85 \mu \mathrm{g} / \mathrm{L})$, total $\mathrm{Cr}(<1.3 \mu \mathrm{g} / \mathrm{L}), \mathrm{Cu}(<1 \mu \mathrm{g} / \mathrm{L}), \mathrm{Ni}(<1 \mu \mathrm{g} / \mathrm{L}), \mathrm{Pb}(<0.75 \mu \mathrm{g} / \mathrm{L})$ and $\mathrm{Zn}(<2.1$ $\mu \mathrm{g} / \mathrm{L})$. For all that, some exceptions for Cd correlated with higher concentrations were remarked in some samples that fail to achieve an acceptable water quality status. Firstly, it is about some water samples that exceeded the permissible limit of Class $1(0.5 \mu \mathrm{g} / \mathrm{L})$, encountered in Trei Ozere $\mathrm{L}$. (DD20-168 $=0.7 \mu \mathrm{g} / \mathrm{L}$, DD20-172 $=0.7 \mu \mathrm{g} / \mathrm{L}$ ) and Radacinos L. (DD20-173 $=0.9 \mu \mathrm{g} / \mathrm{L}$, DD20$174=0.4 \mu \mathrm{g} / \mathrm{L}, \mathrm{DD} 20-176=0.7 \mu \mathrm{g} / \mathrm{L}, \mathrm{DD} 20-179=0.8 \mu \mathrm{g} / \mathrm{L}, \mathrm{DD} 20-180=0.8 \mu \mathrm{g} / \mathrm{L})$. Then, disparate samples overpass the permissible limit of Class $3(1 \mu \mathrm{g} / \mathrm{L})$, as Bogdaproste L. (DD20-143 $=3 \mu \mathrm{g} / \mathrm{L}$; DD20-144 = $2 \mu \mathrm{g} / \mathrm{L}$ ), Trei Ozere L. (DD20-166 = $3 \mu \mathrm{g} / \mathrm{L}$ ) and Radacinos L. (DD20-177 $=2 \mu \mathrm{g} / \mathrm{L})$. The higher $\mathrm{Cd}$ concentrations may result from human-related activities. Among the anthropogenic sources are mentioned industrial effluents and mining activities. Due to the extremely toxic effect on aquatic organisms (zooplankton, fish etc.), continuous monitoring of water quality is recommended, including the repetition of chemical analyzes in sampling sites there where, higher concentrations have been identified.

\section{CONCLUSIONS}

This study was performed to assess the physical-chemical characteristics of surface water collected from three lacustrine environs, namely Bogdaproste, Trei Ozere and Radacinos, in Matita-Merhei hydrographic unit of the Danube Delta. This investigation established that several physical parameters i.e., temperature, electrical conductivity, total dissolved solids, turbidity, total suspended solids and transparency met the standard acceptable limits according to national and international reference standard. As well, several chemical parameters as $\mathrm{pH}$, dissolved oxygen, nutrients, silica, total organic carbon, sulphates, oxido-reduction potential and heavy metals were generally lower than the maximum limit of normal values recommended by the environmental guidelines. Some exceptions related to a higher concentration of orthophosphates and cadmium were found in fewer numbers of water samples. Most likely, these inadvertences can be associated with local conditions of the transitional deltaic environment. Further analysis is required conducting repeated measurements with the same question, meaning orthophosphates and cadmium monitorization. Therefore, overall, the results of this study showed a good quality of water in Bogdaproste, Trei Ozere and Radacinos lakes that did not pose potential health and environmental problems related to the flora and fauna communities. Generally, thus, could be related to the well-known resilience and adaptive capacity of aquatic systems. However, this study recommends a routine surface water monitoring of the Danube Delta Biosphere Reserve, since includes many unique aquatic and terrestrial ecosystems, and is home to thousands of species of flora and fauna, many of them endangered species of animals, birds and fish.

\section{ACKNOWLEDGEMENTS}

The Ministry of Education and Scientific Research - Program Nucleu, supported the research leading to these results: contract 13N/08.02.2019, project code PN 19200203.

\section{REFERENCES}

[1] GUERRY, A.D., POLASKY, S., LUBCHENCO, J., CHAPLIN-KRAMER, R., DAILY, G.C., GRIFFIN, R., RUCKELSHAUS, M., BATEMAN, I.J., DURAIAPPAH, A., ELMQVIST, T., FELDMAN, M.W., FOLKE, C., HOEKSTRA, J., KAREIVA, P.M., KEELER, B.L., LI, S., MCKENZIE, E., OUYANG, Z., REYERS, B., RICKETTS, T.H., ROCKSTROM, J., TALLIS, H., VIRA, B., Proc. Natl. Acad. Sci. 112, 2015, p. 7348.

[2] GRIZZETTI, B., LANZANOVA, D., LIQUETE, C., REYNAUD, A., CARDOSO, A.C., Env. Sci. Policy, 61, 2016, p. 194.

[3] UNITED NATIONS, Millennium development goals reports, New York, USA, 2012, p. 1-44, https://www.un.org/millenniumgoals/pdf/MDG\%20Report\%202012.pdf. 
[4] Directive 2000/60/EC of the European Parliament and of the Council of 23 October 2000 establishing a framework for Community action in the field of water policy, Official Journal of the European Communities, 43 (L327), 2000, p.1.

[5] CHAPMAN, D.V., BRADLEY, C., GETTEL, G.M., HATVANI, I.G., HEIN, T., KOVACS, J., LISKA, I., OLIVER, D.M., TANOS, P., TRASY, B., VARBIRO, G., Environ. Sci. Policy, 64, 2016, p.141, http://dx.doi.org/ 10.1016/j.envsci.2016.06.015.

[6]. SCHERMAN, P.A., MULlER, W., PALMER, C., River Res. Appl., 19, 2003, p. 483.

[7]. NILSSON, C., RENOFALT, B.M., Ecol. Soc., 13, no. 12, 2008, p. 18.

[8] GASTESCU, P., STIUCA, R., The Danube Delta - A Biosphere Reserve, CD Press Publishing House, Bucharest, 2008, p.1-400 [in Romanian].

[9] BRAN, F., IOAN, I., Ecosphere and environmental policies, ASE Publishing House, Bucharest, 2003, p. 1-302, [in Romanian]

[10] PANIN, N., Rev. Roum. Geologie, 55, 2011, p. 41.

[11] ZOCKLER., C., DELANY, S., HAGEMEIJER, W., Wader Study Group Bull., 100, 2003, p. 202-211.

[12] PANIN, N., JIPA, D., Estuar. Coast. Shelf Sci., 54, No. 2, 2002, p. 551.

[13] PANIN, N., JIPA, D.C., GOMOIU, M.T., SECRIERU, D., Environmental Degradation of the Black Sea: Changes and Remedies, NATO Sci. Ser., Springer, New York, 1999, p. 23-41.

[14] RAMSAR CONVENTION, Convention on Wetlands of International Importance especially as Waterfowl Habitat. Ramsar (Iran), 2 February 1971, UN Treaty Series No. 14583, As amended by the Paris Protocol, 3 December 1982, and Regina Amendments, 28 May 1987, Ramsar Convention on Wetlands, Gland, Switzerland.

[15] ISO 11885:2007 - Water quality. Determination of selected elements by inductively coupled plasma optical emission spectrometry (ICP-EOS).

[16] CARR, G., M., NEARY, J.P., Water quality for ecosystem and human health, United Nations Environment Program Global Environment Monitoring System/Water Program, Burlington, Ontario, Canada, 2008, p. 1-120.

[17] CHAPMAN, D., Water Quality Assessments. A Guide to use of biota, sediments and water in environmental monitoring, 2nd edition, University Press, Cambridge, Great Britain, 1996, p. 1-626.

[18] RENDAL, C., KUSK, K.O., TRAPP, S., Environ. Toxicol. Chem., 30, no.11, 2011, p. 2395, doi: 10.1002/etc.641. Epub.

[19] TRIVEDI, P.R., RAJ, G., Encyclopedia of Environmental Sciences, 25, 1992, p.144.

[20] ORDER 161/2006: Standard on surface water quality classification for determination of the ecological status of water bodies, Annex C: Elements and physical-chemical quality standards in water, Romanian Official Monitor, part I, no. 511 bis, 2006 [in Romanian].

[21] CHEN, M., ZENG, G., ZHANG, J., XU, P., CHEN, A., LU, L., Sci. Rep., 5, 2015, https://doi.org/10.1038/srep15043

[22] BRITISH COLOMBIA, Ministry of Environment, Guidelines for interpreting Water Quality Data 1991, p. 30, https://www.for.gov.bc.ca/hts/risc/ pubs/aquatic/interp/interp-01.htm.

[23] DE ZUANE, J., Handbook of Drinking Water Quality, 2nd edition, John Wiley \& Sons Publishing House, 1997, p. 1-575.

[24] DAVIS, M.L., DAVID, A., Introduction to Environmental Engineering, 4th edition, McGrawHill Publishing House, New York, USA, 2008, p. 1-720.

[25] APHA, Standard Methods for the Examination of Water and Wastewater, 21st edition, American Public Health Association, Washington, USA, 2005.

[26] ALLEY, E.R., Water Quality Control Handbook, vol. 2, McGraw-Hill Publishing House, New York, USA, 2007, p. 1-848.

[27] BARTRAM, J., BALLANCE, R., (Eds.), Water Quality Monitoring: A Practical Guide to the Design and Implementation of Freshwater Quality Studies and Monitoring Programmes, Taylor \& Francis Publishing House, New York, USA, 1996, p, 1-383. 
[28] ANZECC 2000 Guidelines, Australian and New Zealand Guidelines for Fresh and Marine Water Quality,http://www.mfe.govt.nz/fresh-water/tools-and-guidelines/anzecc-2000-guidelines [20.07.2021].

[29] HORNE, A.J., GOLDMAN, C.R., Limnology, 2nd edition, McGraw-Hill Publishing House, 1994, p. 1-576.

[30] WETZEL, R. G., Limnology, 2nd edition, Saunders College Publishing House, Philadelphia, USA, 1983, p. 1-760.

[31] COOMBS, T.L., Animals and Environmental Fitness: Physiological and Biochemical Aspects of Adaptation and Ecology, Pergamon Press, New York, USA, 1980, p. 283-302.

Citation: Catianis, I., Grosu, D., Constantinescu, A.M., Tiron Dutu, L., Dobre, O., Physical-chemical properties of the surface water from shallow lakes of the Matita-Merhei Unit, Danube Delta, Romania: current state and environmental significance, Rom. J. Ecol. Environ. Chem., 2021, 3, no.2, pp. 23-31.

(C) 2021 by the authors. This article is an open access article distributed under the terms and conditions of the Creative Commons Attribution (CC BY) license (http://creativecommons.Org/licenses/by/4.0/). 